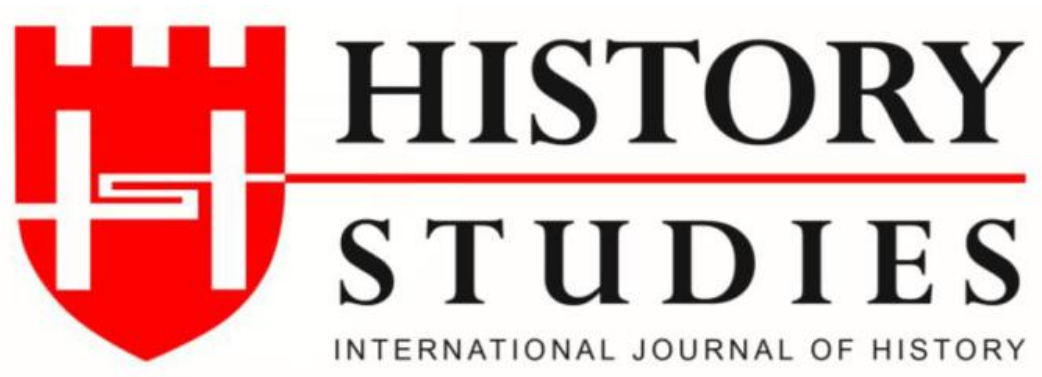

\author{
ISSN: 13094173 (Online) 1309 - 4688 (Print) \\ Volume 12 Issue 4, August 2020 \\ DOI Number: 10.9737/hist.2020.884 \\ Araştırma Makalesi \\ Makalenin Geliş Tarihi: 29.05.2020 Kabul Tarihi: 15.07.2020 \\ Atıf Künyesi: Ahmet Altungök, “Sâsânîler Dönemi İran Tarihi Arkeolojik Kaynakları”, History \\ Studies, 12/4, Ağustos 2020, s. 1419-1439.
}

\title{
Sâsânîler Dönemi İran Tarihi Arkeolojik Kaynakları
}

Iranian Archaelogical Resources of the Sassanids Period

\author{
Doç. Dr. Ahmet Altungök \\ ORCID No: 0000-0003-3777-239X \\ Bilecik Şeyh Edebali Üniversitesi
}

Öz: Sâsânîler dönemi arkeolojik kaynakları, İslam öncesi dönem İran tarihiyle ilgili önemli bilgiler sunmaktadırlar. Bu kaynaklar içerisinde kitabeler, sikkeler, mühürler ve metal eşyalar önemli bir yer tutar. Bu dönemin arkeolojik kaynaklarıyla ilgili olarak çok sayıda bilimsel çalışma yapılmıştır. Sâsânîler dönemi arkeolojik kaynaklarıyla ilgili çalışmalar halen devam etmektedir. Sikkeler ve mühürlerin yer aldığı koleksiyonlarla ilgili çok sayıda katalog çalışması bulunmaktadır. Bu makale, Sâsânîler döneminden kalma kitabe, sikke, mühür ve metal eşyalarla ilgili olarak yapılan çalışmalar hakkında tanıtıcı bilgi vermektedir. Ayrıca Sâsânîler dönemine ait olan kitabelerle ilgili olarak da genel bir bilgi verilmiştir. Bu arkeolojik kaynaklar üzerindeki yazı dili çoğunluk olarak Sâsânîler dönemi İran dili olan Pazand Pehlevicedir. Bu döneme ait olan kitabeler, sikkeler, mühürler ve metal eşyalar üzerindeki yazıların genel olarak çözümü yapılmıştır. Bununla beraber halen daha üzerinde tartışılan çok sayıda konu vardır. Makale çalışmasının kitap boyutuna ulaşmaması için kitabedeki yazıların tam metinleri verilmemiştir. Daha çok bu kitabelerdeki yazıların içeriği hakkında kısa bilgiler verilmiştir. Bu çalışmadan amaç Sâsânîler döneminden kalma arkeolojik verilerle ilgili olarak, bu alanda çalışma yapan araştırmacılar için genel bir bilgi vermektir.

Anahtar Sözcükler: Sâsânî, İran, arkeoloji, kitabe, sikke, mühür, metal eşyalar.

Abstract: Related to Pre-Islamic Period of the Iranian history, archaelogical resources of the Sassanids Period supply significant information. The inscriptions, coins, seals and metallic items have an important place in these sources. Numerous scientific studies have been done on the archaelogical resources of this period. Studies, related to the archaelogical sources of the Sassanids Period are still ongoing. There are a lot of catalog workings about the collections containing coins and seals. This paper ensures introductory information related to the workings on the inscription, coins, seals and metallic items from Sassanids Period. Furthermore, a general information is given about the inscriptions that belong to Sassanids Period. The writing language on these archaelogical resources is predominantly Pazand Pahlavi, an Iranian language of the Sassanids term. The transcription working on these inscriptions, coins, seals and metallic items have generally been made. However there are still a lot of issues that have been discussion about. The texts on these inscription were not fully given to prevent the paper reaching to the size of a book. Mostly, brief information of the content of writings on these inscriptions is given. 
The purpose of this study is to supply general information about the archaelogical data of the Sassanids Period to the researchers working in this field.

Keywords: Sassanids, Iran, archaelogy, inscription, coin, seal, metallic items.

\section{Giriș}

Sâsânî arkeolojik kaynakları içerisinde bize yazılı belgeler sunan kitabeler, sikkeler, mühürler ve metal eşyalar; Sâsânîler dönemi İran tarihinin aydınlatılması açısından çok önemli bilgileri haizdirler. Bu bilgiler Sâsânîler dönemi İran hükümdarlarının hâkimiyet dönemiyle alakalı önemli saptamalar yapmamıza imkân sağlamaktadır. Sâsânîler dönemi sikkelerinden yola çıkarak bu dönemin kitabeleri üzerindeki kabartmaların hangi hükümdarlara ait olduğunun tespiti kolayca yapılabilmiştir. Sâsânî hükümdarlarına ait kitabelerde onların dönemleriyle ilgili önemli olaylardan bahsedilmektedir. Bu kitabelerde, hükümdarlar kronolojik olarak babalarının ve atalarının adlarına da yer verirler. Yazıtlarda sadece İran hükümdarlarına ait bilgilere değil, aynı zamanda Sâsânîler döneminin önemli siyaset adamlarına ait bilgilere de ulaşılmaktadır. Bu dönemin bazı devlet adamlarının İran hükümdarlarından daha büyük bir şöhrete kavuştukları görülmektedir. Kitabelerde verilen bilgilerde, İranlıların Romalılar, Ermeniler, Kuşanlar, Hunlar ve Araplarla ilişkileri hakkında önemli bilgilere ulaşılmaktadır. İran hükümdarları Roma hükümdarlarına karşı kazanmış oldukları zaferlerden bu kitabelerde bahsetmektedirler. İranlıların en önemli rakipleri olan Romalılarla mücadeleleri onların Roma-İran ilişkileri üzerine çok sayıda bilgi vermelerine vesile olmuştur. Yine arkeolojik kaynaklardan İranlıların bayram merasimleri, giyim kuşamları ve hükümdarların tahta çıkma törenleri hakkında önemli bilgilere ulaşmaktayız. Arkeolojik kaynakların hemen hepsinde İranlıların dini inançlarıyla ilgili öğelere oldukça fazla yer verilmiştir. Bu durum, İran mitolojisine ait çok sayıda bilgiye ulaşmamıza imkân sağlar. Bir geç antikçağ imparatorluğu olan Sâsânîlerin tarihini aydınlatmak ve bu alanda bilimsel saptamalar yapmak için arkeolojik kaynaklar önemli bir yere sahiptir. Sâsânîler dönemi İran tarihi üzerine çalışma yapan araştırmacıların mutlaka bu döneme ait arkeolojik kaynaklara göz atması gerekmektedir. Diğer yandan Sâsânîler dönemi İran tarihi arkeolojik kaynakları üzerine araştırmalar yapmış olan bilim insanlarının çalışmaları da bu anlamda önemli bir yere sahiptir. Dolayısıyla bu çalışmada kitabeler, sikkeler, mühürler ve metal eşyalarla ilgili yapılan çalışmalar hakkında da bilgi verilmiştir. Bu anlamda Sâsânîler dönemi arkeolojisine ait kaynaklar iki başlık altında aşağıda olduğu gibi anlatılmıştır.

\section{Kabartma ve Kitabeler}

Sâsânî kitabelerinin yazı dili iki döneme ayrılmaktadır. Sâsânîlerin kuruluşundan hükümdar Nersî (293-302) dönemi sonuna kadar yazılan kitabeler genel olarak Aramaik Pehlevîce, Pazand Pehlevîce ve Yunancayla yazılmıştır. Parthların yıkılışından sonraki dönemde İran topraklarındaki yaygın dil olan Parthça ve Yunanca bir müddet varlığını devam ettirmiştir. Bu dönem İran coğrafyasında yaşayan toplulukların hepsi yazılanları anlasın diye yazıtlar üç ayrı dille yazılmıştır. Nersî'den sonra ise yazıtların artık genel olarak Sâsânîler dönemi Pehlevîcesi ve Derî dilinde yazılmış oldukları görülmektedir. Doğu İran coğrafyası üzerinde yazılan 
kitabelerde ise Pehlevîceye daha az yer verilmekle beraber Soğdca ve Toharca yaygın bir dil olarak karşımıza çıkmaktadır ${ }^{1}$.

Kertir Yazıtları: Kertir'e ait farklı kitabeler bulunmaktadır. Bunlardan bir tanesi Nakş-1 Receb yazıtlarında yer almaktadır². Bu kitabe, Pehlevîce yazılmış 31 satır yazıdan meydana gelmektedir $^{3}$. Bu kitabede Kertir, kendisinin cennet ve cehenneme düzenlemiş olduğu miracından ve Mazdeizm dinine bağlılı̆ğıdan bahsetmektedir. Ayrıca kendisine ait bir portre I. Erdeşîr'in (224-241) tahta çııış törenini gösteren kabartmalarda da yer alır. Nakş-1 Rüstem kitabesinde I. Şâpûr'un (241-272) zaferini gösteren bir kabartmada da onun atının yanında durmaktadır. I. Nersî'ye ait olan Paykuli kitabesinde de Kertir'den bahsedilmektedir. Yaşadı̆̆ 1 dönemde önemli bir din adamı olan Kertir'in; Tenser ile aynı kişi olduğu ilk olarak Herzfeld tarafından öne sürülmüştür ${ }^{4}$. Bunun yanında Kertir'in adı I. Şâpûr döneminden itibaren 293 yılına kadarki birçok yazıt ve metinde görülmektedir. Nakş-1 Receb yazıtında bu devlet adamı kendisinden krtyr şeklinde bahsetmiştir ${ }^{5}$. Bundan dolayı adı Kartir, Kertir, Kirder, Kirdir şeklinde farklı olarak ifade edilmektedir. Yaşadığı dönemde namı İran topraklarını aşan bu din ve siyaset adamının isminden Grek, Koptik ve Maniehist metinler de bahsetmişlerdir. Nakş-1 Rüstem'deki Kertir Kitabesini ilk olarak çözümleyen bilim adamı İngiliz oryantalist Thomas Hyde (1636-1703)'dir. Fakat bu kitabenin çözümlenmesi ve bazı sözcüklerin yorumlanmasında çok sayıda bilim insanının katkısı vardır. Danimarkalı bilim insanı Carsten Niebuhr (17331815); İngiliz müstemleke görevlisi William Ouseley (1767-1842); İskoç yazar, seyyah ve diplomat Robert K. Porter (1777-1842); İngiliz bilim insanları Edward Thomas (1813-1886) ve Edward W. West (1824-1905); Alman bilim insanları Ernest E. Herzfeld (1879-1948), Walther Hinz (1906-1992), İsveçli bilim insanı H. S. Nyberg (1889-1974), Amerikalı bilim insanı R. N. Frye (1920-2014), Rus bilim insanları W. B. Henning (1908-1967), V. Lukonin (1932-1984), Fransız bilim insanı Philippe Gignoux ve bunların yanında M. L. Chaumont, J. de Menasce, C. J. Brunner; Kertir ile ilgili olarak Nakş-1 Receb, Paykuli, Sare Maşhad kitabeleri üzerinde çalışan bilim insanlarıdır. Bu çalışmaların hepsinin kritiğiyle beraber son olarak Kertir ile ilgili çalışmalar Gignoux, D. N. MacKenzie ve Frantz Grenet tarafından yapılmıştır ${ }^{6}$.

\footnotetext{
${ }^{1}$ Dönemin İran dilleri hakkında geniş bilgi için bkz. Perviz Natel Hânlerî, Tarihe Zabane Farsî, c. I, Neşre Nov, Çaphâneye Ketîbe, Tehrân 1365(hş): 271vd; Sâsânî kitabeleri üzerindeki Yunan etkisiyle ilgili olarak bkz. Ernst E. Herzfeld, Archaeological History of Iran, The Schweich Lectures of the British Academy, Published for the British Academy, By Humphrey Milford, Oxford University Press, London, 1935: 76vd.

2 Tûrac Deryâyî, "Ketîbeyî Kertîr der Nekşe Receb", Nâmey-i Îrân Bâstân, Sâle Evvel, Şomâreye Evvel, Behâr ve Tâbestân, 1380: 1-10.

${ }^{3}$ Nimet Yıldırım, "Fars Edebiyatında Metafizik Yolculuklar", Doğu Esintileri: Iranoloji, Fars Dili ve Edebiyatı Araştırmaları Dergisi (A Journal of Iranology Studies), sy. 2, Erzurum, 2014/12: 185.

${ }^{4}$ Prods Oktor Skjærvø, "Kartir", EI, vol. XV, fasc. 6, 2011: 608-628.

${ }^{5}$ D. H. Jamaspasa and Martin Haug, An Old Pahlavi-Pazand Glossary, Published by Order of the Government of Bombay, Bombay and London, 1870: 65.

${ }^{6}$ Skjærvø, 2011: 608-628.
} 
Nakş-ı Rüstem: Nakş-1 Rüstem; antik Persepolis kentinin kuzeyinde bulunan Kuh-1 Hüseyn'in (Hüseyn Dağı) güneye bakan tarafındaki dik yamacı üzerinde yer almaktadır. Dağın bu yüzü Persler döneminde yapılan gömme kral mezarlarıyla doludur. Kral mezarlarının altında da Sâsânîler döneminde yapılan kabartma ve kitabeler yer almaktadır. Bu kabartmalardan bir tanesi I. Erdeşîr'e aittir. Ahûrâ Mazdâ'nın elinden hükümdarlık halkasını alan I. Erdeşîr'in atının ayakları altında Ehrimen ve son Parth kralı V. Artabanos (216-224) bulunmaktadır ${ }^{7}$. I. Erdeşîr'e ait olan kitabe Sâsânîler dönemine ait en eski kitabedir. Bu kitabenin yazıları Sâsânîler dönemi Pehlevîcesi, Parthça ve Yunanca yazılmıştır. Küçük bir kitabenin en üstünde üç satır Pehlevîce ve Partça onların altında da dört satır Yunanca yazı bulunmaktadır ${ }^{8}$. Nakş-1 Rüstem'de yer alan bir diğer kabartma I. Şâpûr'a aittir. Bu kabartma I. Şâpûr'un Romalılara karşı kazanmış olduğu Edessa Savaşı'nın (259-260) anısına yapılmıştır. Kabartmada Roma imparatoru Valerianus (253-260), I. Şâpûr'un önünde diz çökmüş ve bağışlanma dilemektedir' I. Şâpûr'un atının üzerinde Pazand Pehlevîce, Aramaik Pehlevîce ve Yunanca yazılar vardır. Fakat 5 satırdan oluşan Yunanca yazının haricindekiler zarar görmüş ve silinmişlerdir. Nakş-1 Rüstem'deki diğer bir kabartma ise I. Nersî'nin taç takma töreni ile ilgilidir. Bu kabartmada I. Nersî, Anahita ${ }^{10}$ olduğu tahmin edilen bir kadından tacını alırken resmedilmiştir. Ayrıca kabartmalarda çocuk motifleri de yer almaktadır. Bazı İranologlar, kadının Anahita değil de bir kraliçe olduğunu iddia etmektedirler ${ }^{11}$. Ayrıca Nakş-1 Rüstem'de yukarıda belirttiğimiz gibi Kertir'e ait 79 satırdan oluşan bir kitabe yer almaktadır ${ }^{12}$.

Hacıâbad: Bu kitabe, antik Persepolis kentinin birkaç kilometre kuzeyinde, günümüzde Hacıabâd adı verilen bir köyün karşısında yer almaktadır. Sâsânî hükümdarı I. Şâpûr tarafindan bir kaya üzerine yazdırılmıştır ${ }^{13}$. Aynı kitabe, Tang-i Burak'ta da yer almaktadır. İlk defa 1818 y1lında Robert Ker Porter tarafindan incelenmiştir. Daha sonra H. S. Nyberg ve Walter Bruno Henning tarafından incelenerek bazı düzeltmeler yapılan kitabeye ait metin, 1978 yılında David N. MacKenzie tarafından yayınlanmıştır ${ }^{14}$. Kitabede kendisini İranlı olanların ve İranlı

\footnotetext{
${ }^{7}$ A. V. Williams Jackson, Persia, Past and Present: A Book of Travel and Research, The Macmillan Company, London, 1906: 220.

${ }^{8}$ Ahmed Tefazzolî, Târîhe Edebiyâte Irân Pîş ez Eslâm, (Be Kûşeşe Dr. Jâle Âmûzgâr), Ketâbhâneye Milliye Îrân, Tehrân, 1376(hş): 84; Muhammed Cevâd Meşkûr, Nâmey-i Bâstân (Mecmû'aye Makâlât), (Thk. Sa'îd Mîr Muhammed Sâdık, Nâdire Celâlî), Tehrân, 1378(hş): 525.

${ }^{9}$ Ernst E. Herzfeld, Iran in the Ancient East, Archaeological Studies Presented in the Lowell Lectures as Boston, Oxford University Press, London and New York, 1941: 314; R. N. Frye, "The Political History of Iran Under the Sasanians", The Cambridge History of Iran, vol. 3(1), (Edited by Ehsan Yarshater), 2000: 126; Roman Girişman, Irâne Bâstân, (Trc. Ya'kûb Âjend), İntişârât-1 Mevlâ, Tehrân,1385(hş): 107.

${ }^{10}$ Selevkos etkisinden dolayı İran toprakları üzerinde Anahita kültü yayılmıştır. Parthlar döneminde ve Sâsânîlerin ilk dönemlerinde bu tanrıçaya tapanlar bulunmaktaydı. Erdeşir'in atası Sâsân, İstahr şehri yakınlarında Anahita’ya adanmış bir tapınağın başrahibiydi. Bkz. Ahmet Altungök, İslam Öncesi Iran 'da Devlet ve Ekonomi, Hikmetevi Yayınları, İstanbul, 2015, s. 45, 46, 302, 337.

${ }^{11}$ Frye, 2000: 121.

12 Yildırım, 2014: 188, 189.

${ }^{13}$ Meşkûr, 1378(hş): 524, 525.

${ }^{14}$ Philippe Gignoux, "Hajiabad Inscriptions", EI, vol. XI, fasc. 5, 2002: 554-555.
} 
olmayanların hükümdarı olarak tanıtan I. Şâpûr, babası Erdeşîr ve büyükbabası Papak (Günümüz tabiriyle Babek) ile övünür. Kendisini Mazdaperest olarak tanımlayan hükümdar ok atmanın inceliğinden, okun kıymetli bir silah olduğundan ve ok atmada mahir olan kimselerin taltif edilmesinden bahseder. Kitabe, İranlıların meşhur "ok atma bayramı" olan tirgân ile alakalı olarak yazılmıştır. Kitabenin aynısı Tang-i Burak'ta da görülmekle beraber buradaki kitabeye fazladan üç satır eklenmiştir. Kitabenin üzerindeki 21 satır yazının ilk on altı satırı Parthça geri kalanı ise Pazand Pehlevîce yazılmıştır ${ }^{15}$.

Paykuli: Bu kitabe günümüz Irak toprakları üzerinde bulunmaktadır. Konum olarak Kasr-1 Şirin ile Süleymaniye arasında yer alır. Bu kitabe Sâsânî başkenti Tîsfûn (Ctesiphon) ile Tebrîz arasındaki antik ana yol üzerinde, Sâsânî hükümdarı I. Nersî tarafından diktirilmiştir. Parthça ve Pazand Pehlevîce yazılmıştır. Kitabenin batı tarafında 46 satır Pehlevîce, doğu tarafında 43 satır Parthça yazı bulunmaktadır. Kitabenin başlangıcında Nersî kendisinden ve nesebinden bahsetmekte, devamında II. Behrâm'ın ölümünden Ermenistan seferine kadarki olaylardan bahsetmektedir. Ayrıca III. Behrâm'ın yenilgisinden ve Romalılarla yapılan anlaşmadan bahseder. İlk defa Herzfeld tarafından neşredilen kitabedeki yazıların daha sonraları Humbach ve Skjaervo tarafından da ayrıca neşirleri yapılmışıır ${ }^{16}$.

Nakş-1 Receb: Bu kitabe Taht-1 Cemşid'in üç kilometre kuzeyindedir. I. Şâpûr'un 241 yılında tahta çıkışını gösteren bir kabartma Nakş-1 Receb'de yer almaktadır. Bu kabartma I. Erdeşîr'in Nakş-1 Rüstem'de tahta çıkışını gösteren kabartmanın benzeridir. Her iki kabartmada bu hükümdarlar kendileriyle aynı kıyafeti giyinmiş olan birisinin elinden taç alırken resmedilmişlerdir ${ }^{17}$. Bu kişinin genelde Ahûrâ Mazdâ (Ormazd) olduğu iddia edilir ${ }^{18}$. Nakş-1 Receb'deki kabartmalardan bir tanesinde yine I. Şâpûr ata binmiş bir şekilde resmedilmiştir ve Sâsânî soyluları süvari oldukları halde kendisinin arkasından gelmektedirler. I. Şâpûr'a ait kabartmanın üzerinde 5 satır Pazand Pehlevîce, 4 satır Aramaik Pehlevîce ve 6 satır Helenistik Yunanca yazı bulunmaktadır. Ayrıca I. Erdeşîr'in taç takma törenine ait farklı bir kabartma da Nakş-1 Receb'de yer almaktadır. Nakş-1 Receb'deki diğer bir kitabe Kertir'e ait olup yukarıda bahsedilmiştir.

Kâbe-i Zerdüşt: Antik Persepolis şehrinin yaklaşı 9,2 km kuzeyinde yer alan Nakş-1 Rüstem kitabelerine bakan açık alanda yer almaktadır. Küpe benzer yapısından dolayı kâbe şeklinde ifade edilmiştir. Bu şekilde isimlendirilmesi İslâm sonrası dönemde gerçekleşmiştir. Kesin bir bilgiye dayanmamakla beraber İslâm sonrası dönem Mazdeistleri arasında Zerdüşt'ün mezarının bu yapının altında olduğu inancı yayılmaya başlamıştır. Bulunduğu zeminin bir miktar altında etrafı bir kaç basamaklı olarak inşa edilen bu yapının kapısının önünde yine

\footnotetext{
15 Tefazzolî, 1376(hş): 85; Meşkûr, 1378(hş): 524.

16 Prods Oktor Skjaervo, "Herzfeld and the Paikuli Inscription", EI, vol. XII, fasc. 3, 2003: 298-300; Tefazzolî, 1376(hş): 93, 94. Ayrıca bkz Meşkûr, 1378(hş): 525, 526.

${ }^{17}$ Arthur Kristensen, Irân der Zemâne Sâsânîyân: Tarîhe Îrâne Sâsânî ta Hamleye Arab ve Vaz'e Devlet ve Millet der Zemâne Sâsânîyân, Donyâye Ketâb, Tehrân, 1368(hş): 259.

${ }^{18}$ Herzfeld, 1941: 311.
} 
basamaklı bir merdiven bulunur. Persler döneminde inşa edilen bu yapının batı cephesinde Parthlar dönemi Pehlevîcesiyle yazılmış 30 satılık bir kitabe bulunmaktadır. Bunun yanında yapının güney cephesinde ise 70 satırdan oluşan Yunanca bir kitabe bulunmaktadır. Ayrıca doğu duvarında da Sâsânîler dönemi Pehlevîcesiyle yazılmış 35 satırlık bir metin bulunmaktadır $^{19}$. Bu yazıtlar I. Şâpûr tarafından yazılmış olup; kendisinin Doğu Roma imparatoru Gordianus (238-244) ve Valerianus'a karşı kazandığı zaferlerden, Gordianus'un yerine geçen Philippus'un (244-249) vergiye bağlanmasından bahseder. Doğu duvarındaki Pehlevîce yazıların altında da Kertir'in kendisine ait bir kitabe yer almaktadır ${ }^{20}$. Bu kitabe 19 satırdan oluşmaktadır. Kertir bu kitabesinde başka dinlerle mücadelesinden, Sâsânî hükümdarlarına ve Mazdeizm dinine yaptığı hizmetlerden bahseder ${ }^{21}$. Kâbey-i Zerdüşt'ün etrafinda 1936 yılında E. F. Schmidt ve sonrasında David Stronach düzenli olarak kazı çalışması yapmışlardır. Yapılan araştırmaların sonunda bu yapının bir ateş tapınağı mı veya bir arşiv binası $\mathrm{m} 1$ yahut anıt mezar mı olduğu konusunda netlik kazanmayan bazı yaklaşımlarda bulunmuşlardır. Sâsânîler döneminde binanın duvarına yazılan metinlerde binanın hangi amaçla kullanıldığı ve kim tarafından yapıldığına dair bilginin olmaması bu dönemde İranlıların yapıyla ilgili herhangi bilgiye sahip olmadıklarına yorumlanmıştır. Bununla beraber W. B. Henning, Kertir'e ait olan kitabede bu binadan "bûn-ḩânâk" şeklinde bahsedildiğini ve bunun da "vakıf evi" anlamına gelebileceği üzerinde durmuştur.

Sare Maşhad: Bu kitabe Kazrûn'un 80 km güneyinde yer almakta ve Cerre'ye $36 \mathrm{~km}$ mesafededir. Kitabede, Behrâm Gûr'un vahşi bir hayvanın saldırısına uğrayan bir kadını kurtarmaya çalıştı̆̆ını gösteren bir kabartma bulunmaktadır ${ }^{22}$. Ayrıca Sare Maşhad'da Kertir'e ait bir kitabe de yer almaktadır. Kitabe 58 satır yazıdan oluşmaktadır. Kertir 25. satıra kadar I. Şâpûr'dan itibaren II. Behrâm dönemine kadar yaptığı hizmetlerden, bu hükümdarlar döneminde ele geçirilen yerlerden, Mazdeizm dinine olan bağlılığından bahseder. 26. satırdan sonra da yaptığı miraçtan ve öldükten sonraki yaşamdan bahsederek Mazdeistlere öğütler verir $^{23}$.

Ebnûn Kitabesi (Barme Delak): Şîrâz şehrinin 10 km doğusunda Barme Delak adı verilen yerde bulunan ${ }^{24}$ bu kitabe III. Şâpûr döneminde dikilmiştir. Bu kitabe bir ateşdânın dört tarafına resmedilen tasvir ve yazılardan oluşur. Bu tasvirlerden bir tanesi I. Erdeşîre, iki tanesi III. Şâpûr'a ve diğeri saray komutanı Ebnûn'a aittir. Kitabenin etrafında ateşgâhın inşasıyla alakalı üç satır yazı yazılmıştır. Barme Delak'te yer alan diğer bir kitabede bir Sâsânî şehzâdesi ve bayanın resmi yer almakla beraber kitabe üzerindeki 5 satır yazı oldukça zarar görmüştür. Büyük ihtimalle yazı, kabartmada resimleri bulunan kimseleri tanıtmak için yazılmıştı.

\footnotetext{
${ }^{19}$ Tefazzolî, 1376(hş): 85 .

${ }^{20}$ Gerd Gropp, "Ka'ba-ye Zardoşt", EI, vol. XV, fasc. 3, 2009: 271-272.

${ }^{21}$ Yildirim, 2014: 185vd.

${ }^{22}$ Herzfeld, 1941: 325.

${ }^{23}$ Tefazzolî, 1376(hş): 91, 92; Girişman, 1385(hş): 107; Yıldırım, 2014: 186.

${ }^{24}$ Mîlâd Vendâ'î, "Behrâme Devvom der Gûyûm ve Barme Delak II, III", Sasanika Archaeology 20, 2014: 4 .
} 
Tak-ı Bûstân: Kirmanşah'ın 5 km kuzey doğusunda yer almaktadır. Tak-1 Bûstân'daki kabartmalardan bir tanesi II. Erdeşîr'in tahta çıkma törenine aittir. Kabartmada II. Erdeşîr, birisinin elinden hükümdarlık menşurunu almaktadır. II. Erdeşîr'e hükümdarlık menşurunu veren kişinin arkasında da birisi bulunmaktadır ve başının arkasında güneş motifi bulunmaktadır. Hükümdarlık menşurunu alan veya veren kişinin ayaklarının altında ise alt edilmiş bir düşman motifi yer almaktadır. Hükümdarlık menşurunu veren kişinin II. Erdeşîr'in selefi II. Şâpûr, başının etrafında güneşten bir hale bulunan kişinin ise Mithra olduğu varsayılır. Fakat hükümdarın taç takma merasimi genelde önceki hükümdar öldükten sonra gerçekleştirilir. Çoğunlukla taç din adamları reisi tarafından hükümdara takılır. Başının etrafında güneşten bir hale olan kişinin ise Mazdeizm dininin peygamberi olan Zeraster olma ihtimali yüksektir. Mazdeizm dininde tanrı Ahura-mazda resmedilmemiştir. Eski İran dininde tanrıların resmedilmesi geleneği olmadığı için bu şahsın Mithra olması imkân dâhilinde görülmemektedirr ${ }^{25}$. Tak-1 Bûstân'daki diğer bir kabartma ise II. ve III. Şâpûr'a ait olan kabartmadır $^{26}$. Küçük bir oyma kemerin içerisinde yer alan bu kabartmada her iki hükümdar da iki elleriyle bir kılıca yaslanmışlar ve bir birlerine doğru bakmaktadırlar. Bu kabartmaların yanında her iki hükümdara ait birkaç satır ifade Pehlevîce yazılmıştır. II. Şâpûr'un kitabesi 9 satır, III. Şâpûr'un kitabesi ise 13 satırdan oluşmaktadır. Tak-1 Bûstân'daki büyük kemerin içerisinde ise II. Hüsrev'e ait olan kabartmalar yer almaktadır. Eyvanın birinci katında II. Hüsrev atı Şebdiz ile birlikte resmedilmiştir ${ }^{27}$. Kemerin ikinci katında ise yine II. Hüsrev'in Ahura-mazda ve Anahita tarafından kutsandığını gösteren bir kabartmanın yer aldığına inanılmaktadır. Fakat bu kabartmadaki kişilerin kimlere ait olduğu halen daha tartışmalıdır. Kemerin her iki tarafında sarmaşık şeklinde hayat ağacı ve ağaçların üst kısmında kanatlı melek figürleri yer almaktadır. Ayrıca Tak-1 Bûstân'da hükümdarların av merasimini gösteren sahneler, arp çalan kadınlar resmedilmiştir.

Tange Burak Kitabesi: Hacıabâd'ın yaklaşık yüz kilometre kuzey batısında Dozkûrd yakınlarında bir vadinin su kenarında bulunmaktadır. Aramaik Pehlevîce ve Pazand Pehlevîce yazılmış olan bu kitabenin yazısı birkaç satırı hariç Hacı Abâd yazıtlarının aynısıdır. I. Şâpûr tarafindan yazdırılmıştı́ ${ }^{28}$.

Dura Europos Yazıtları: Günümüz Suriye toprakları üzerinde Fırat nehri kenarında elSalhiyah'ın güney doğusunda yer almaktadır ${ }^{29}$. Antik Mari kentinin kuzeyinde yer alan bu bölge I. Şâpûr tarafından ele geçirilmiştir. Dura'daki kitabelerden bir tanesi bu şehirdeki bir sinagogun duvarında yer almaktadır. Anlaşıldığına göre bu yazı, şehri fetheden ordunun kâtiplerinden bir müdür tarafından yazılmıştır. Yazı hem Sâsânîler dönemi Pehlevîcesi ve hem

\footnotetext{
${ }^{25}$ Farklı yaklaşım ve izahlar için bkz. Herzfeld, 1935: 79vd.

${ }^{26}$ Meşkûr, 1378(hş): 526.

${ }^{27}$ Jackson, 1906: 524, 525.

28 Tefazzolî, 1376(hş): 85.

29 Bkz. Simon James, "Stratagems, Combat, and "Chemical Warfare" in the Siege Mines of DuraEuropos", American Journal of Archaeology, v. 115, 2011: 69-101.
} 
de Parthlar dönemi Pehlevîcesiyle yazılmıştır. Bununla beraber yine bu şehirde ele geçirilen çanak çömlekler üzerinde Sâsânîler dönemi Pehlevîcesiyle yazılmış yazılar tespit edilmiştir. O dönemin tüccarları tarafindan yazılan bu yazılar dönemin fiyatları ve ekonomik yapısıyla ilgili önemli bilgiler içermektedir. Ayrıca Dura şehrinde ele geçirilen bir deri parçası üzerinde en erken Sâsânî yazısı örneğine ait idari yazışmalarda kullanmış bir kıta Parthça ve iki kıta Pehlevîce yazı bulunmaktadır ${ }^{30}$.

Gûyûm Kabartması: Bu kabartma Şiraz şehrinin 27 km kuzey batısında yer almaktadır ${ }^{31}$. Kitabe Herzfeld tarafından keşfedilerek 1926 yılında bir makaleyle ilim dünyasına tanıtılmıştır. Kabartma üzerinde çalışma yapan diğer bir tarihçi Aurel Stein'dir. Kabartmanın Sâsânî hükümdarı II. Behrâm döneminde yaptırıldığg zannedilir.

Debîr Epesâ (Efesâ) Yazıtları: I. Şâpûr'un Epesâ adındaki müdürlerinden (debîr/diphâr) bir tanesi tarafından 266 yılında yazılmıştır. 1936 yılında Roman Grishman tarafından Kazrûn bölgesindeki Bişâpûr şehrinde yapılan çalışmalarla tespit edilmiştir. Kitabede 16 satır Pehlevîce ve 12 satır Parthça yazı yer almaktadır ${ }^{32}$.

Bîşâpûr Kitabeleri: Kitabe ilk olarak I. Behrâm tarafından diktirilmiştir. Fakat daha sonra Nersî aynı kitabeyi kendi adına uyarlamıştır. Kitabenin üzerinde 11 satır Pehlevîce yazı bulunmaktadır. Kitabede Nersî kendisinden ve nesebinden bahseder. Bîşâpûr kitabelerinden bir tanesi de I. Şapûr'a aittir. Bu kitabe yine Parthça ve Sâsânî Pehlevîcesiyle yazılmıştır ${ }^{33}$.

Şâpûr Segenşâh Kitabesi: Bu kitabe Taht-1 Cemşîd'in güney girişindeki bir sütunun üzerine 311 yılında yazılmıştır. 11 satırdan oluşan yazı Segenşâh unvanlı Şâpûr adındaki bir şâhî'nin II. Şâpûr'u ziyaretini anlatmaktadır ${ }^{34}$.

Selûk Kitabesi: Sâsânî hükümdarı II. Şâpûr'un Kabil ve Câvîdşâpûr kadısı olan Selûk'un, hükümdarın iktidarının on sekizinci yılında kendisini ziyareti üzerine yazdırmış olduğu 11 satırdan oluşan Pehlevîce kitabedir. Son iki kitabe batılı iranologlar Ouseley, Stolze, Hertzfeld, Nayberg, Henning ve Frye tarafindan okunmasına rağmen metin üzerinde halen daha çok sayıda tartışılan nokta bulunmaktadır ${ }^{35}$.

Meşkîn Kitabesi: Güney Azerbaycan şehirlerinden Meşkîn'de tespit edilen kitabe 21 satırdan oluşmaktadır. Meşkîn şehrinde Nersî döneminde yapımına başlanan bir kalenin

\footnotetext{
${ }^{30}$ Tefazzolî, 1376(hş): 88, 89.

${ }^{31}$ Vendâ'î, 2014: 4.

32 Tefazzolî, 1376(hș): 89, 90.

${ }^{33}$ Meşkûr, 1378(hş): 525, 526.

34309 yılında henüz annesinin karnındayken hükümdar ilan edilen II. Şapur'un bu görüşme sırasında iki yaşında olması da ilginç bir konudur. Tafazzolî, Şâpûr Segenşâh'ın II. Hürmüz'ün oğlu ve II. Şâpûr'un da kardeşi olduğunu söyler. Bu durumda neden kendisi yerine annesinin karnındaki II. Şâpûr hükümdar yapılmıştır. Bu da tartışılması gereken bir konudur. Bkz. Meşkûr, 1378(hş): 526.

35 Tûrac Deryâyî, "Ketibey-i Pehlevî Selûk, Dâver-i Kâbil", Ferheng, Vijeye Zaban Şenâsî, Şomâre 4950, Behâr ve Tâbestân, 1383: 46-51.
} 
duvarına asılıdır. Kalenin yapımı II. Şâpûr döneminde tamamlanmıştır. Kitabeden anlaşıldığına göre kalenin inşası Şâpûr'un iktidarının 27. (335) yılında tamamlanmıştır ${ }^{36}$.

Mihr Nersî Kitabesi: Şîrâz'nn yüz on altı km güneyinde Fîrûzâbâd yakınlarında, Sâsânîler döneminden kalma bir köprüde bulunmaktadır. 7 satırdan oluşan Pehlevîce kitabe I. Yezdicürd (399-420), Behrâm Gûr (420-438) ve II. Yezdicürd (438-457) dönemlerinde vezirlik yapmış olan Sâsânî devlet adamı Mihr Nersî tarafından yazdırılmıştır ${ }^{37}$.

Tirmiz Kitabesi: Özbekistan toprakları içerisinde günümüz Karatepe'de bir Budist mağarasında yer alan yazıt; debîr ünvanlı birisi tarafından, IV. yüzyılda Pehlevîce yazılmış küçük bir kitabedir.

Ulyâ Kitabeleri: Pakistan'ın kuzeyinde Hunza'daki Sind vadisinde yer alan Ulya'da bulunan IV. yüzyıla ait 670 yazıtın iki tanesi Parthça, iki tanesi Pehlevîce, on tanesi Toharca ve geri kalanları Soğd alfabesiyle yazılıdır.

\section{Sâsânîler Dönemi Sikke, Mühür ve Gümüş Eşyaları}

Sâsânîler dönemi İran tarihinin diğer önemli kaynağı sikkelerdir. Sâsânî dönemi sikkeleri sayesinde, bu dönemden kalma kaya kabartmaları üzerindeki hükümdar motiflerinin kimlere ait olduğunun tam olarak tespiti yapılabilmiştir. Ayrıca bu dönemden kalma sikkeler sayesinde 36 Sâsânî hükümdarından 32 tanesinin hükümdarlık dönemleri net olarak tespit edilebilmiştir. Bu dönemden kalma sikkeler genelde gümüş, az sayıda altın sikke ve bunların yanında bakır ve bronz sikkelerden oluşmaktadır. Bu sikkeler üzerindeki yazılar çoğunlukla Sâsânîler dönemi Pehlevîcesi olup Pazand alfabesiyle yazılmıştır. Dolayısıyla sikkeler üzerinde çalışma yapabilmek için Pazand alfabesini bilmek gerekmektedir. Günümüzde İran Milli Kütüphanesinin dökümünde 4424 adet Sâsânî sikkesi bulunmaktadır. Bu sikkelerin iki ayr1 katalog halinde tanıtımı yapılmıştır ${ }^{38}$. Birinci katalogda toplam 1476 adet sikke ile 102 tabağın tanıtımı yapılmıştır. İkinci katalogda ise 2948 sikke ile 352 adet tabağın tanıtımı yer almaktadir.

Princeton Üniversitesinin kendi kütüphanesine kazandırmış olduğu Robert Schaaf koleksiyonunda ise 723 adet Sâsânî sikkesi bulunmaktadır. Bu sikkelerden 17 tanesi altın, 600

\footnotetext{
${ }^{36}$ R. N. Frye and P. O. Skjaervo, "The Middle Persian Inscription from Meshkinshahr", Bulletin of the Asia Institute, New Series, vol. 10, Studies in Honor of Vladimir A. Livshits, 1996: 53; Tefazzolî, 1376(hş): 95 .

${ }^{37}$ Tefazzolî, 1376(hş): 96.

${ }^{38}$ Kataloglardan birincisi Vesta Sarkhosh Curtis, M. E. Askari, E. J. Pendleton, R. Hodges, A. A. Safi tarafindan, Sâsânîan Coins, A Sylloge of the Sasanian Coins in the National Museum of Iran (Muzeh Melli Iran, Tehran), Volume I, Ardashir I-Hormizd IV. başlığı altında düzenlenmiş ve 2010 yılında yayınlanmıştır. Diğer cildi ise yine Vesta Sarkhosh Curtis, M. E. Askari, E. J. Pendleton, R. Hodges, A. A. Safi tarafindan A Sylloge of the Sasanian Coins in the National Museum of Iran (Museh Melli Iran, Tehran), Volume II, Khusrau II-Yazdgard III, başlığıyla düzenlenmiş ve 2012 yılında yayınlanmıştır.
} 
tanesi gümüş, 7 tanesi alaşım, 92 tanesi bakır ve 7 tanesi kurşundan yapılmıştır ${ }^{39}$. Bu koleksiyon üzerine Nickolaus Schindel'in bir katalog çalışması bulunmaktadır. Günümüzde Sâsânî sikkeleri ile ilgili olarak çok sayıda çalışma yapılmıştır. Nickolaus Schindel'in "Sylloge Nummorum Sasanidarum Israel", "Sasanian Mint Abbreviations, The Evidence of Style" ve "The Begginin of Kushano-Sasanian Coinage" adlı çalışmaları önemlidir ${ }^{40}$. Schindel, birinci çalışmasında İsrail müzelerinde yer alan yaklaşık 1800 adet Sâsânî sikkesinin tanıtımını yapmaktadır. İkinci çalışmasında ise Sâsânî sikkeleri üzerindeki sembol ve yazıların kısaltmaları hakkında bilgi vermektedir. Üçüncü çalışmasında da Sâsânî hükümdarlarından şehzade oldukları dönemde Kuşân eyaletine Kuşânşâh unvanıyla atanmış olanların kendi adlarına bastırmış oldukları sikkelerin tanıtımını yapmaktadır. Bunun yanında Schindel'in Sâsânî sikkeleri üzerinde yer alan kısaltmaların ne anlama geldikleriyle ilgili olarak "Sâsânîan Mint Abbreviations: The Evidence of Style" başlıklı önemli bir makalesi bulunmaktadır ${ }^{41}$. Sâsânî nümizmatiği ile ilgili bir diğer önemli çalışma ise William H. Valentine'nin Sassanian Coins başlıklı 134 sayfalık çalışmasıdır ${ }^{42}$. Ayrıca Carlo G. Cereti’nin "Some Notes on the Sasanian Coinage of Esfehan and a Few Mint Signatures" adlı makalesi de bu alanda yapılan önemli çalışmalardan bir tanesidir ${ }^{43}$. Cereti, bu makalesinde İsfahan'a ait olan bazı Sâsânî sikkelerinin tanıtımını yapmaktadır. Vesta Sarkhosh Curtis'in "Some Observations on Coins of Peroz and Kavad I" ve "Observations on Some coins of Persis" adlı çalışmaları önemlidir ${ }^{44}$. Curtis, birinci çalışmasında British Museum'un Sâsânî sikkeleri koleksiyonunda yer alan Sâsânî hükümdarları Pirûz ve I. Kubâd'a ait olan sikkelerin tanıtımını yapmıştır. Yazar, ünlü Alman iranolog Klaus Schippmann (1924-2010) anısına yapmış olduğu ikinci çalışmasında ise Sâsânîler dönemi sikkeleri üzerindeki sembollerin tanıtımını yapmıştır.

Touraj Daryaee'nin "The Use of Religio-Political Propaganda on the Coinage of Xusro II", "The Coinage of Queen Boran and Its Significance for Late Sasanian Imperial Ideology" ve "History, Epic and Numismatics: On the Title of Yazdgerd I (Ramşahr)" adlı Sâsânî sikkeleri

\footnotetext{
39 Nikolaus Schindel, Sylloge Nummorum Sasanidarum the Schaaf Collection, Herausgegeben von Michael Alram und Rika Gyselen, Wien, 2014: 9, 10, 11, 12.

${ }^{40} \mathrm{Bu}$ çalışmaları için bkz. Nikolaus Schindel, Sylloge Nummorum Sasanidarum Israel, Österreichischen Akademie Der Wissenschaften, Wien, 2009; "Sasanian Mint Abbreviations, The Evidence of Style", The Numismatic Chronicle, v. 165, 2005: 287-299; "The Begginin of Kushano-Sasanian Coinage", Sylloge Nummorum Sasanidarum, Paris, Berlin, Wien, 2012: 65-74.

${ }^{41}$ Nikolaus Schindel, "Sasanian Mint Avvreviations: The Evidence of Style", The Numismatic Chronicle (1966-), v. 165, Published Royal Numismatic Society, (2005): 287-299.

${ }^{42}$ William H. Valentine, Sassanian Coins, Spink and Son. Ltd, London, 1921.

${ }^{43}$ Bkz. Carlo G. Cereti, "Some Notes on the Sasanian Coinage of Esfehan and a Few Mint Signatures", La Persia e Bisanzio, Rome, 2004: 309-326.

${ }^{44}$ Bkz. Vesta Sarkhosh Curtis, "Some Observations on Coins of Peroz and Kavad I", Coins, Art and Archaeology, (Eds. M. Alram and D. E. Klimburg-Salter), Essays on the pre-Islamic History of the IndoIranian Borderlands, 1999: 303-313; "Observations on Some coins of Persis", Faszination Iran Beitrage zur Religion, Geschichte und Kunst des Alten Iran, Gedenkschrift für Klaus Schippmann, Herausgegeben von Shervin Farridnejad, Rika Gyselen und Anke Joisten-Pruschke, Harrassowitz Verlag, Wiesbaden, 2015: 25-38. 
üzerine yaptığı çalışmaları bulunmaktadır ${ }^{45}$. Birinci makalesini, II. Hüsrev dönemine ait sikkeler üzerindeki sembol ve yazıların İranlıların dini inançları açısından önemiyle ilgili olarak yazmıştır. İkinci makalesini kraliçe Burandoht'a ait sikkelerin üzerindeki yazıların Sâsânîlerin dini inançlarıyla alakası üzerine yazmıştır. Üçüncü makalesinde ise I. Yezdicürd'e ait bir sikke üzerindeki yazıların tanıtımını yapmaktadır.

Bunlara ek olarak Burandoht dönemi sikkeleriyle ilgili olarak Malek ve Curtis'in birlikte çalışmış oldukları "History and Coinage of the Sasanian Queen Boran" başlıklı bir makale çalışması da önemlidir" ${ }^{46}$. Sâsânîler dönemi sikkeleriyle alakalı; 1793 ve 2010 yılları arasında yapılmış bilimsel çalışmalarla ilgili olarak, Touraj Daryaee ve Andrea Gariboldi'nin birlikte hazırlamış oldukları "A Bibliography of Sasanian and Arab-Sasanian Numismatics (17932010)" başlıklı bibliyografik makale çalışması bu konuyla ilgili derli toplu bir liste sunması açısından önemli bir yere sahiptir. Rika Gyselen'in Arab-Sasanian Copper Coinage ve Michael Alram ile beraber hazırladıkları Sylloge Nummorum Sasanidarum: Band I: Ardashir I - Shapur I ve Sylloge Nummorum Sasanidarum: Band II: Hormazd I - Hormazd II, Sâsânî nümizmatik çalışmaları açısından önemlidir ${ }^{47}$. Birinci çalışma İslam sonrası dönemde Müslümanlar tarafından İran coğrafyası üzerinde bastırılan sikkeler hakkında bilgi vererek bu paralar üzerindeki Sâsânî etkisinden bahsetmektedir. 330 adet sikkenin tanıtımının yapıldığı bu çalışma Michael Alram ile yapılan diğer iki çalışmanın devamıdır. Sylloge Nummorum Sasanidarum ise 6 ciltten oluşan bir çalışmanın ilk iki cildidir. Bu çalışmalarda Viyana, Berlin ve Paris müzelerinde yer alan 11.000 adet Sâsânî sikkesinin tanıtımı yapılmıştır.

Andrea Gariboldi'nin Sasanian Coinage and History: The Civic Numismatic Collection of Milan ile Sylloge Nummorum Sasanidarum Tajikistan - Sasanian Coins and Their Imitations from Sogdiana and Toachristan adlı çalışmaları Sâsânî sikkeleri üzerine yapılan önemli çalışmalardan iki tanesidir ${ }^{48}$. Birinci çalışmada Milano koleksiyonunda yer alan 69 Sâsânî gümüş sikkesinin tanıtımı yapılmıştır. İkinci çalışma ise İran'da son dönemde ortaya çıkarılan 1267 adet dirhem üzerinde yapılan çalışmaları kapsamaktadır. Bu çalışmada Sâsânîler

\footnotetext{
${ }^{45}$ Bazı çalışmaları için bkz. Touraj Daryaee, "The Use of Religio-Political Propaganda on the Coinage of Xusro II", American Journal of Numismatics, vol. 9, The American Numismatic Society, New York, 1997: 41-57; "The Coinage of Queen Boran and Its Significance for Late Sasanian Imperial Ideology", Bulletin of the Asia Institute, vol. 13 (1999): 77-82; "History, Epic and Numismatics: On the Title of Yazdgerd I (Ramşahr)", American Journal of Numismatics (1989-), vol. 14 (2002): 89-95.

${ }^{46}$ Hodge Mehdi Malek and Vesta Sarkhosh Curtis, "History and Coinage of the Sasanian Queen Boran (AD 629-631)", The Numismatic Chronicle (1966-), vol. 158 (1998): 113-129.

${ }^{47}$ Rika Gyselen, Arab-Sasanian Copper Coinage, Published Austrian Academy of Sciences Press, Wien, 2000; Michael Alram and R. Gyselen, Sylloge Nummorum Sasanidarum: Band I: Ardashir I - Shapur I, Published by Austrian Academy of Sciences Press, Wien, 2003; Sylloge Nummorum Sasanidarum: Band II: Hormazd I - Hormazd II, Published by Verlag der Osterreichischen Akademie der Wissenschaften, Wien, 2012.

${ }^{48}$ Andrea Gariboldi, Sasanian Coinage and History: The Civic Numismatic Collection of Milan, Mazda Publishers, California, 2010; ... Sylloge Nummorum Sasanidarum Tajikistan - Sasanian Coins and Their Imitations from Sogdiana and Toachristan, Published by Austrian Academy of Sciences Press, Wien, 2017.
} 
döneminde darbedilen 708 adet sikke yer almakla beraber diğerleri İslam sonrası dönem Sâsânî sikkelerinin taklitlerinden oluşmaktadır. Bunun yanında Larissa Baratova ve Nikolaus Schindel'e ait Sylloge Nummorum Sasanidarum Usbekistan adlı katalog çalışması bulunmaktadır $^{49}$. Bu çalışmada Soğdiana coğrafyası üzerinde ele geçirilmiş olan Sâsânî dönemi ve sonrasına ait olan sikkelerin tanıtımı yapılmıştır.

Robert Göbl'ün Sasanian Numismatics adlı kitabı, Sâsânîler dönemi sikkeleriyle ilgili önemli çalışmalardan bir tanesidir ${ }^{50}$. Yüz sayfadan oluşan katalog çalışması 16 sayfalık bir tablo ile Sâsânî paralarının tanıtımını içermektedir. Sâsânî nümizmatik çalışmaları noktasında A. D. Mordtmann'ın Zur Pehlevi-Münzkunde adlı çalışması da önemli bir yere sahiptir ${ }^{51}$. Kendisi, Sâsânî sikkeleri üzerindeki Pehlevice yazıların anlamları, hükümdarlar lakapları ve semboller hakkında kapsamlı bir çalışma ortaya koymuştur. Amîn Amînî, Sikkeşenâsî Akherîn Şâhâne Sâsânî adlı çalışmasında Sâsânî sikkelerinden elde ettiği veriler 1şığında Şireveyh'ten sonra iktidara gelen son Sâsânî hükümdarlarının hükümdarlık sürelerinin tespitini yapmaya çalışmıştır ${ }^{52}$. Susan Tyler-Smith The Coinage Reforms (600-603) of Khusru II and the Revolt of Vistâhm, adlı çalışmasında Sâsânî hükümdarı II. Hüsrev döneminin 591 ile 602 yılları arasına ait olan 562 adet sikkenin tanıtımını yapmaktadır. Yine aynı yazar "Coinage in the Name of Yazdgerd III (AD 632-651) and the Arab Conquest of Iran" başlıklı çalışmasında Sâsânîlerin son hükümdarı III. Yezdicürd dönemine ait sikkelerin ayrıntılı bir kataloğunu sunmaktadır. Bu çalışmada anılan döneme ait 179 adet sikkenin tanıtımı yapılmıştır ${ }^{53}$.

J. M. Unvala, Taberistan ve Huzistan bölgesine ait olan Sâsânî sikkeleri üzerine çalışarak; çalışma sonuçlarını, Coins of Tabaristan and Some Sassanian Coins from Susa adlı kitabında yayınlamıştır ${ }^{54}$. Malik Îrej Moşî̂î'nin Études de numismatique iranienne sous les Sassanides adlı nümizmatik bir çalışması bulunmaktadır ${ }^{55}$. Bu kitap Farsça ve Fransızca yayınlanmıştır. Ayrıca aynı tarihçiye ait Arab-Sasanian Civil War Coinage adıyla Sâsânîlerin son dönemlerinde Arap-İran savaşları sırası ve sonrasında darbedilen sikkelerle ilgili bir kitap çalışması bulunmaktadır ${ }^{56}$. Bunun yanında Hodge Malek'in İslam sonrası dönem İran ve Irak’tal

49 Larissa Baratova, Nikolaus Schindel, Sylloge Nummorum Sasanidarum Usbekistan, Verlag der Österreichischen Akademie der Wissenchaften, Wien, 2012.

${ }^{50}$ Robert Göbl, Sasanian Numismatics, Published by Klinkhardt and Biermann, Braunschweig, 1971.

51 Andreas D. Mordtmann'ın “Zur Pehlevi-Münzkunde IV”, ZDGM, v. 33, (1879), 82-142; ... “Zur Pehlevi-Münzkunde V”, ZDGM, v. 34, (1880), 1-162.

${ }^{52}$ Amîn Amînî, Sikkeşenâsî Akherîn Şâhâne Sâsânî, İntişârât-1 Pâzîne, Yezd, 1392(hş).

${ }^{53}$ Susan Tyler-Smith, The Coinage Reforms (600-603) of Khusru II and the Revolt of Vistâhm, Royal Numismatic Society Special Publication No. 54, London, 2017; "Coinage in the Name of Yazdgerd III (AD 632-651) and the Arab Conquest of Iran", The Numismatic Chronicle (1966-), vol. 160 (2000): 135170.

${ }^{54}$ Jamshedji Maneckji Unvala, Coins of Tabaristan and Some Sassanian Coins from Susa, Maisonneuve, Paris, 1938.

${ }^{55}$ Malik Îrej Moșîrî, Etudes de numismatique iranienne sous les Sassanides, Bibliotheque Nationale, Tehran, 1972.

${ }^{56}$ Malik Îrej Moşî̂î, Arab-Sasanian Civil War Coinage; Manichaeans, Yazidiya and Other Khawarij, Publisher Pazineh, 2010. 
darbedilen Arap-Sâsânî sikkeleriyle ilgili iki ciltten oluşan bir çalışması bulunmaktadır. ArabSasanian Numismatics and History During the Early Islamic Period in Iran and Iraq adl çalışmasını British Museum'un kataloğundaki sikkeleri inceleyerek hazırlamıştır ${ }^{57}$. Kendisinin Sâsânîler dönemi nümizmatiği ile ilgili çok sayıda makalesi yer almaktadır ki bunlardan bahsetmek konunun uzamasına sebep olacağından dolayı bahsedilmeyecektir. Ayrıca David Jongeward, Joe Cribb ve Peter Donovan'ın, American Numismatic Society'in dökümünde bulunan Kûşân sikkeleri üzerine bir katalog çalışmaları bulunmaktadır. Kushan, KushanoSasanian, and Kidarite Coins adını verdiği bu çalışmada Kûşân-Sâsânî sikkeleri önemli bir yer tutmaktadır ${ }^{58}$. Kuşân-Sâsânî sikkeleri üzerinde çalışma yapan diğer bir bilim adamı da C. J. Brunner'dir. Kendisinin bu konuyla ilgili olarak The Chronology of the Sasanian Kusansahs adında güzel bir makale çalışması bulunmaktadır ${ }^{59}$. Bununla beraber Eduard Khorshudian ile Armine Zohrebian'ın Ermenistan coğrafyasına ait olan Sâsânî sikkeleriyle ilgili olarak hazırlamış oldukları Sassanian Coins of Armenia adlı 173 sayfadan oluşan bir kitap çalışması da Sâsânî nümizmatiği açısından yapılmış önemli bir çalışmadır ${ }^{60}$.

Bu alanda yapılan önemli çalışmalardan bir diğeri de John Walker'ın Arap-Sâsânî sikkeleri üzerine hazırlamış olduğu 496 sayfadan oluşan bir katalogdur. İslam sonrası dönemde Araplar tarafından taklitleri yapılan sikkeler üzerine yapılan bir çalışmadır ${ }^{61}$. John Walker, British Museum'da yer alan Arap-Sâsânî paraları üzerinden katalog çalışmasını ortaya koymuştur. Bir diğer nümizmatik çalışma Furdoonjee D. J. Paruck'a aittir. Kendisinin Sasanian Coins adıyla 536 sayfalık bir çalışması bulunmaktadır ${ }^{62}$. N. Nakşibendi ve F. Raşid'in Irak müzelerinde bulunan Sâsânî sikkeleriyle ilgili olarak yazmış oldukları Sassanian Dirhems in the Iraq Museum adlı çalışma da önemlidir ${ }^{63}$. Ayrıca Çek Cumhuriyetinde yer alan müzelerdeki Sâsânî sikkeleri üzerine yapılmış olan bir proje çalışması da önemlidir. Vlastimil Novak, Rika Gyselen, Jaroslav Frana ve Jiri Militki tarafından gerçekleştirilen proje çalışmasında Prag müzelerinde bulunan Sâsânî sikkeleriyle ilgili katalog çalışması yapılmıştır ${ }^{64}$. Bunun yanında David Sellwood, Philip D. Whitting ve Richard Williams'ın Sâsânîler dönemi sikkeleri

\footnotetext{
${ }^{57}$ Hodge Malek, Arab-Sasanian Numismatics and History During the Early Islamic Period in Iran and Iraq, Royal Numismatic Society, London, 2019.

${ }^{58}$ David Jongeward, Joe Cribb and Peter Donovan, Kushano-Sasanian, and Kidarite Coins: A Catalogue of Coins from the American Numismatic Society (Ancient Coins in North American Collections), New York, 2015.

59 Christopher J. Brunner, "The Chronology of the Sasanian Kusansahs", Museum Notes (American Numismatic Society), vol. 19, 1974: 145-164.

${ }^{60}$ Eduard Khurshudian and Armine Zohrabian, Sassanian Coins of Armenia, National Academy of Sciences of Armenia, 2002.

${ }^{61}$ John Walker, A Catalogue of the Arab-Sassanian Coins, The British Museum Printed by Order of the Trustees, London, 1941.

${ }^{62}$ Furdoonjee D. J. Paruck, Sasanian Coins, Times Press, Bombay, 1924.

${ }^{63}$ N. Nakshabandi and F. Rashid, "Sassanian Dirhems in the Iraq Museum", Sumer, vol. 11/2, (1955): 154-176.

64 Bkz. Vlastimil Novak and Others, Corpus Sasanicus: Numismata Orientalia Regni Bohemiae, National Museum, Prague, 2000.
} 
hakkında 178 sayfadan oluşan bir kitap çalışmaları bulunmaktadır ${ }^{65}$. Ayrıca Gürcistan'da ele geçirilmiş olan Sâsânî sikkeleriyle ilgili olarak M. Tsotselia'nın bir kitap çalışması bulunmaktadır. 96 sayfadan oluşan kitap çeşitli kazılarda ele geçirilmiş Sâsânî dirhemleri ile ilgili bilgiler vermekle beraber kitap; haritalar ve grafiklerle zengin bir görsele sahiptir ${ }^{66}$. Yukarıda belirtmiş olduğumuz kitap ve makaleler, Sâsânî sikkeleri üzerine yapılan önemli çalışmalardır. Sâsânîler döneminden kalma sikkeler üzerinde yapılan çalışmalar bu dönem hükümdarlarıyla ilgili yeterli kronolojik bilgi sunmaktadır.

Ayrıca Sâsânîler dönemi İran tarihinin önemli kaynaklarından bir tanesi de bu dönemden kalma mühürlerdir. Bu mühürlerle ilgili Saeedi ailesinin 131 mühürden oluşan bir koleksiyonu bulunmaktadır. Bu koleksiyonla ilgili R. Gyselen'in Sasanian Seals and Sealings in the A. Saeedi Collection başlıklı bir çalışması vardır ${ }^{67}$. Yine aynı yazarın Saedi koleksiyonunda yer alan sikkelerle ilgili New Evidence for Sasanian Numismatics; The Collection of Ahmad Saeedi başlıklı bir çalışması da bulunmaktadır ${ }^{68}$. Bununla beraber New York'ta bulunan Metropolitan Museum of Art'1n dökümünde Sâsânîler dönemine ait 243 tane mühür yer almaktadır. Buradaki mühürlerle ilgili olarak Christopher J. Brunner'in Sasanian Stamp Seals in the Metropolitan Museum of Art adıyla bir katalog çalışması bulunmaktadır ${ }^{69}$. Sâsânîler dönemi mühürleriyle ilgili diğer bir katalog çalışması da A.D.H. Bivar tarafından yapılmıştır. Adı geçen tarihçi British Museum'da yer alan hükümdar mühürleriyle alakalı olarak hazırladığı çalışmasını Catalogue of the Western Asiatic Seals in the British Museum: Stamp Seals II, The Sassanian Dynasty başlığıyla ortaya koymuştur ${ }^{70}$. Bir diğer koleksiyon da Edward Gans'a (1887-1991) aittir. Kendisine ait koleksiyonda yaklaşık olarak 400 Sâsânî mührü bulunmaktadır. Guitty Azarpay'ın başında bulunduğu bazı bilim insanları Edward Gans Seal Collection'da yer alan bu mühürler üzerinde çalışmışlar ve yaptıkları çalışmayı "Sasanian Seals from the Collection of the Late Edward Gans, at the University of California, Berkeley" başlığıyla elektronik ortamda yayınlamışlardır.

Sâsânîler dönemi mühürleriyle alakalı olarak R. N. Frye'nin Sasanian Remains from Qasr-ı Abu Nasr. Seals, Sealings and Coins adıyla bir çalışması bulunmaktadır ${ }^{71}$. Sâsânîler dönemi İran tarihine ait arkeolojik kaynaklarla ilgili bir diğer zengin koleksiyon Muhsin Furugî’ye

65 David Sellwood, Philip D. Whitting and Richard Williams, An Introduction to Sasanian Coins, Publisher Spink and Son, London, 1985.

${ }^{66}$ Medea Tsotselia, History and Coin Finds in Georgia: Sasanian Coin Finds and Hoards, Moneta, Wetteren, 2003.

67 Rika Gyselen, Sasanian Seals and Sealings in the A. Saeedi Collection (ACTA Iranica), Peeters Publishers, 2007.

${ }^{68}$ Rika Gyselen, New Evidence for Sasanian Numismatics; The Collection of Ahmad Saeedi, Paris, 2004.

${ }^{69}$ Çalışma için bkz. Christopher J. Brunner, Sasanian Stamp Seals in the Metropolitan Museum of Art, New York, 1978.

70 A.D.H. Bivar, Catalogue of the Western Asiatic Seals in the British Museum: Stamp Seals II, The Sassanian Dynasty, London, 1969.

${ }^{71}$ R. N. Frye, Sasanian Remains from Qasr-ı Abu Nasr: Seals, Sealings and Coins, Harvard University Press, Cambridge, 1974. 
(1907-1983) aittir. Kendisi ünlü iranolog Roman Grişman'in tavsiyesi üzerine bu dönemden kalma, sikke, mühür, tabak, çanak ve çömleklere ait büyük bir koleksiyon oluşturmuştur. Koleksiyonuna ait bazı ürünleri Louvre Müzesine hediye eden Furugî’nin, geriye kalan tarihi eserleri İran Antik Eserler Müzesine aktarılmıştır. Bu koleksiyonda yer alan mühürlerle ilgili olarak R.N. Frye'nin bir katalog çalışması bulunmaktadır ${ }^{72}$. Sâsânîler dönemi mühürler ve üzerindeki yazılarla ilgili olarak Agostini ve Shaked tarafından yazılmış olan "Two Sasanian Seals of Priests" başlıklı bir makale çalışması bulunmaktadır ${ }^{73}$. Ayrıca A. G. Gubaev, S. D. Loginov ve A. B. Nikitin tarafından Türkmenistan'ın güneyinde yer alan Artık'daki Aktepe mevkiinde gerçekleştirilen arkeolojik kazılarda ortaya çıkarılan Sâsânî mühürleriyle alakalı raporları önemlidir. Burada elde edilen mühürler bir makalede katalog halinde sunulmuştur ${ }^{74}$. Bu çalışmada 48 mühür baskısı ve mührün tanıtımı yapılmıştır.

Ayrıca bu mühürlerin dışında İran tarihiyle alakalı olarak önemli bir diğer kaynak ise bu dönemden günümüze ulaşmış olan gümüş kaplardır. Bu gümüş kaplar üzerinde Sâsânîler dönemi İran kültür ve medeniyetine ait birçok öğe yer almaktadır. Ayrıca bu gümüş eşyaların birçoğunda Sâsânîler dönemi İran'ına ait alım satım işleriyle ilgili bilgiler veren mühürler ve damgalar yer almaktadır. Bu konuyla ilgili olarak O. Harper ve P. Meyer'in, The Metropolitan Museum of Art'in dökümünde bulunan gümüş eşyalarla ilgili Silver Vessels of the Sasanian Period adıyla bir katalog çalışmaları bulunmaktadır ${ }^{75}$. Bununla beraber Edward Thomas'ın Sâsânîler dönemi yazıtları ve sikkeleriyle beraber bu dönem mühürleri hakkında hazırlamış olduğu 137 sayfa hacmindeki Early Sassanian Inscriptions, Seals and Coins başlıklı çalışması da önemlidir ${ }^{76}$. Bunun yanından W. Ouseley'in Sâsânî hükümdarlarına ait madalya ve mücevherler üzerindeki yazılarla ilgili olarak hazırlamış olduğu 61 sayfadan oluşan bir kitap çalışması yer almaktadır. Bu çalışmasında tarihçi, kıymetli metaller üzerindeki hükümdar lakapları ve tanımlamalar üzerinde durmuştur ${ }^{77}$.

\section{Sonuç}

Sâsânîler dönemi İran tarihinin arkeolojik kaynakları incelendiğinde; bu kaynakların genel anlamda kitabeler, sikkeler, mühürler ve madeni eşyalar olduğu görülmektedir. Bu dönemden günümüze ulaşabilen kitabelerin sayısı 19 adettir. Kitabeler üzerindeki yazılar genel anlamda çözülmüş olmakla beraber henüz üzerinde tartışılan çok sayıda konunun da bulunduğu

\footnotetext{
72 R. N. Frye, Sasanian Seals in the Collection of Mohsen Foroughi, Published Lund Humphries, London, 1971.

${ }^{73}$ Domenico Agostini and Shaul Shaked, "Two Sasanian Seals of Priests", Bulletin of the Asia Institute, New Series, vol. 27 (2013): 99-105.

${ }^{74}$ A. G. Gubaev, S. D. Loginov and A. B. Nikitin, "Sasanian Bullae from the Excavations of Ak-Depe by the Station of Artyk", Iran, vol. 34, Publisher Taylor and Francis, 1996: 55-59.

${ }^{75}$ Bkz. Prudence O. Harper, Pieter Meyers, Silver Vessels of the Sasanian Period, v. I: Royal Imagery, Published in Association with Princeton University Press, 1981.

${ }^{76}$ Edward Thomas, Early Sassanian Inscriptions, Seals And Coins, London, 1968.

${ }^{77}$ William Ouseley, Observations on Some Medals and Gems, Bearing Inscriptions in the Pahlavi or Ancient Persick Character, Printed at the Oriental Press, London, 1801.
} 
görülmektedir. Kitabelerde, İran hükümdarlarının kendi dönemlerinde gerçekleşen siyasi ve dini olaylar hakkında birinci ağızdan bilgiler vermeleri; İslam öncesi dönem Ön Asya tarihi araştırmaları açısından önemli bir yere sahiptir. Sâsânîler döneminden günümüze kadar ulaşmış olan sikkeler ve mühürler de bu dönem İran tarihi hakkında önemli bilgiler sunmaktadır. Bu sikke ve mühürler, bu dönem hükümdarları ile bunların hükümdarlık dönemleri hakkında yeterli veri sağlamaktadır. Sâsânîler döneminden günümüze ulaşan sikke ve mühürlerle ilgili çok sayıda katalog çalışması yer almaktadır. Bu çalışmalar Sâsânîler dönemi İran tarihi üzerine çalışma yapan araştırmacılar için zengin bir kaynak sunmaktadır.

Sâsânîler döneminin arkeolojik kaynakları incelendiğinde bu kaynakların ana dillerinin genelde Aramaik Pehlevîce, Pazand Pehlevîce ve Helenistik Yunanca ile kısmen Soğdca, Toharca ve Süryanca olduğu görülmektedir. Bundan dolayı Sâsânîler dönemi İran tarihi üzerine çalışma yapmak isteyen bir araştırmacının bu antik dillerden en az bir tanesini bilmesi gerekmektedir. Özellikle, Sâsânîler dönemi İran'ının yazı dilleri olan Pazand Pehlevîce veya Aramaic Pehlevîce dillerinden en az bir tanesinin bilinmesi gerekmektedir. $\mathrm{Bu}$ dönemin bütünüyle alakalı olarak en çok karşımıza çıkan dil ise Pazand Pehlevicedir. Sâsânîler dönemine ait kitabeler ve sikkelerin okunması amaciyla mutlaka bilinmesi gereken dil Pazand Pehlevîcedir. Dönemin kitabe ve metin dillerinden bir tanesinin bilinmesi araştırmacının sentez ve yorum gücünü artırması açısından zaruridir. Bu döneme ait yazıtların ve metinlerin modern batı dillerine de başarılı bir şekilde çevirileri yapılmıştır. Dolayısıyla antik dillere ek olarak Almanca, Fransızca ve İngilizce gibi batı dillerinden en az bir tanesinin de bilinmesi Sâsânîler dönemi İran tarihi çalışmaları açısından önemlidir. Sâsânîler dönemi sikkeleri, mühürleri ve arkeolojik verileriyle ilgili hazırlanan koleksiyon ve katalogların büyük çoğunluğunun İngilizce yazıldığı da görülmektedir.

\section{Kaynakça}

\section{Nümizmatik Çalışmalar ve Kataloglar}

ALRAM, Michael and R. Gyselen, Sylloge Nummorum Sasanidarum: Band I: Ardashir I Shapur I, Published by Austrian Academy of Sciences Press, Wien, 2003.

ALRAM, Michael and R. Gyselen, Sylloge Nummorum Sasanidarum: Band II: Hormazd I Hormazd II, Published by Verlag der Osterreichischen Akademie der Wissenschaften, Wien, 2012.

AMÎNÎ, Amîn, Sikkeşenâsî Akherîn Şâhâne Sâsânî, İntişârât-1 Pâzîne, Yezd, 1392(hş).

BARATOVA, Larissa; SCHINDEL, Nikolaus, Sylloge Nummorum Sasanidarum Usbekistan, Verlag der Österreichischen Akademie der Wissenchaften, Wien, 2012.

BRUNNER, Christopher J., Sasanian Stamp Seals in the Metropolitan Museum of Art, New York, 1978. 
CERETİ, Carlo G., "Some Notes on the Sasanian Coinage of Esfehan and a Few Mint Signatures", La Persia e Bisanzio, Rome, 2004, pp. 309-326.

CURTIS, Vesta Sarkhosh, M. E. Askari, E. J. Pendleton, R. Hodges, A. A. Safi, Sâsânîan Coins, A Sylloge of the Sasanian Coins in the National Museum of Iran (Muzeh Melli Iran), Volume I, Ardashir I-Hormizd IV. Tehran, 2010,

CURTIS, Vesta Sarkhosh, Sâsânian Coins, A Sylloge of the Sasanian Coins in the National Museum of Iran (Museh Melli Iran), Volume II, Tehran, Khusrau II-Yazdgard III, London, 2012.

CURTIS, Vesta Sarkhosh, "Some Observations on Coins of Peroz and Kavad I", Coins, Art and Archaeology, (Eds. M. Alram and D. E. Klimburg-Salter), Essays on the pre-Islamic History of the Indo-Iranian Borderlands, 1999, pp. 303-313.

CURTIS, Vesta Sarkhosh, "Observations on Some coins of Persis", Faszination Iran Beitrage zur Religion, Geschichte und Kunst des Alten Iran, Gedenkschrift für Klaus Schippmann, Herausgegeben von Shervin Farridnejad, Rika Gyselen und Anke Joisten-Pruschke, Harrassowitz Verlag, Wiesbaden, 2015, pp. 25-38.

DARYAEE, Touraj, "The Use of Religio-Political Propaganda on the Coinage of Xusro II", American Journal of Numismatics, vol. 9, The American Numismatic Society, New York, 1997, pp. 41-57.

DARYAEE, Touraj, "The Coinage of Queen Boran and Its Significance for Late Sasanian Imperial Ideology", Bulletin of the Asia Institute, vol. 13, 1999, pp. 77-82.

DARYAEE, Touraj, "History, Epic and Numismatics: On the Title of Yazdgerd I (Ramşahr)", American Journal of Numismatics (1989-), vol. 14, 2002, pp. 89-95.

GARIBOLDI, Andrea, Sasanian Coinage and History: The Civic Numismatic Collection of Milan, Mazda Publishers, California, 2010.

GARIBOLDI, Andrea, Sylloge Nummorum Sasanidarum Tajikistan - Sasanian Coins and Their Imitations from Sogdiana and Toachristan, Published by Austrian Academy of Sciences Press, Wien, 2017.

GÖBL, Robert, Sasanian Numismatics, Published by Klinkhardt and Biermann, Braunschweig, 1971.

GYSELEN, Rika, Arab-Sasanian Copper Coinage, Published Austrian Academy of Sciences Press, Wien, 2000.

GYSELEN, Rika, New Evidence for Sasanian Numismatics; The Collection of Ahmad Saeedi, Paris, 2004. 
GYSELEN, Rika, Sasanian Seals and Sealings in the A. Saeedi Collection (ACTA Iranica), Peeters Publishers, 2007.

HARPER, Prudence O. and Pieter MEYERS, Silver Vessels of the Sasanian Period, v. I: Royal Imagery, Published in Association with Princeton University Press, 1981.

JONGEWARD, David, Joe CRIBB and Peter DONOVAN, Kushano-Sasanian, and Kidarite Coins: A Catalogue of Coins from the American Numismatic Society (Ancient Coins in North American Collections), New York, 2015.

KHURSHUDIAN, Eduard and Armine ZOHRABIAN, Sassanian Coins of Armenia, National Academy of Sciences of Armenia, 2002.

MALEK, Hodge, Arab-Sasanian Numismatics and History During the Early Islamic Period in Iran and Iraq, Royal Numismatic Society, London, 2019.

MOŞÎRÎ, Malik Îrej, Etudes de numismatique iranienne sous les Sassanides, Bibliotheque Nationale, Tehran, 1972.

NOVAK, Vlastimil and others, Corpus Sasanicus: Numismata Orientalia Regni Bohemiae, National Museum, Prague, 2000.

PARUCK, Furdoonjee D. J., Sasanian Coins, Times Press, Bombay, 1924.

SCHINDEL, Nikolaus, Sylloge Nummorum Sasanidarum Israel, Österreichischen Akademie Der Wissenschaften, Wien, 2009.

SCHINDEL, Nikolaus, "Sasanian Mint Abbreviations, The Evidence of Style", The Numismatic Chronicle, v. 165, 2005, pp. 287-299.

SCHINDEL, Nikolaus, "The Begginin of Kushano-Sasanian Coinage", Sylloge Nummorum Sasanidarum, Paris, Berlin, Wien, 2012, pp. 65-74.

SCHINDEL, Nikolaus, Sylloge Nummorum Sasanidarum the Schaaf Collection, Herausgegeben von Michael Alram und Rika Gyselen, Wien, 2014.

TYLER-SMITH, Susan, The Coinage Reforms (600-603) of Khusru II and the Revolt of Vistâhm, Royal Numismatic Society Special Publication No. 54, London, 2017.

TYLER-SMITH, Susan, "Coinage in the Name of Yazdgerd III (AD 632-651) and the Arab Conquest of Iran", The Numismatic Chronicle (1966-), vol. 160, 2000, pp. 135-170.

VALENTíNE, William H., Sassanian Coins, Spink and Son. Ltd, London, 1921.

WALKER, John, A Catalogue of the Arab-Sassanian Coins, The British Museum Printed by Order of the Trustees, London, 1941. 


\section{Araştırma Eserler}

ALTUNGÖK, Ahmet, İslam Öncesi Iran'da Devlet ve Ekonomi, Hikmetevi Yayınları, İstanbul, 2015.

BIVAR, A.D.H., Catalogue of the Western Asiatic Seals in the British Museum: Stamp Seals II, The Sassanian Dynasty, London, 1969.

FRYE, R. N., Sasanian Seals in the Collection of Mohsen Foroughi, Published Lund Humphries, London, 1971.

FRYE, R. N., Sasanian Remains from Qasr-ı Abu Nasr: Seals, Sealings and Coins, Harvard University Press, 1974.

GİRIŞMAN, Roman, Îrâne Bâstân, (Trc. Ya'kûb Âjend), İntişârât-1 Mevlâ, Tehrân, 1385(hş).

HÂNLERÎ, Perviz Natel, Tarihe Zabane Farsî, c. I, Neşre Nov, Çaphâneye Ketîbe, Tehrân, 1365(hş).

HERZFELD, Ernst E., Archaeological History of Iran, The Schweich Lectures of the British Academy, Published for the British Academy, By Humphrey Milford, Oxford University Press, London, 1935.

HERZFELD, Ernst E., Iran in the Ancient East, Archaeological Studies Presented in the Lowell Lectures as Boston, Oxford University Press, London and New York, 1941.

JACKSON, A. V. Williams, Persia, Past and Present: A Book of Travel and Research, The Macmillan Company, London, 1906.

JAMASPASA, D. H. and Martin HAUG, An Old Pahlavi-Pazand Glossary, Published by Order of the Government of Bombay, Bombay and London, 1870.

KRISTENSEN, Arthur, Îrân der Zemâne Sâsânîyân: Tarîhe Îrâne Sâsânî ta Hamleye Arab ve Vaz'e Devlet ve Millet der Zemâne Sâsânîyân, Donyâye Ketâb, Tehrân, 1368(hş).

MEŞKÛR, Muhammed Cevâd, Nâmey-i Bâstân (Mecmû'aye Makâlât), (Thk. Sa'îd Mîr Muhammed Sâdık, Nâdire Celâlî), Tehrân, 1378(hş).

MOŞÎRÎ, Malik Îrej, Arab-Sasanian Civil War Coinage; Manichaeans, Yazidiya and Other Khawarij, Publisher Pazineh, 2010.

OUSELEY, William, Observations on Some Medals and Gems, Bearing Inscriptions in the Pahlavi or Ancient Persick Character, Printed at the Oriental Press, London, 1801.

SELLWOOD, David; Philip D. WHITTING and Richard WILLIAMS, An Introduction to Sasanian Coins, Publisher Spink and Son, London, 1985.

THOMAS, Edward, Early Sassanian Inscriptions, Seals And Coins, London, 1968. 
Sâsânîler Dönemi İran Tarihi Arkeolojik Kaynakları

TSOTSELIA, Medea, History and Coin Finds in Georgia: Sasanian Coin Finds and Hoards, Moneta, Wetteren, 2003.

UNVALA, Jamshedji Maneckji, Coins of Tabaristan and Some Sassanian Coins from Susa, Maisonneuve, Paris, 1938.

\section{Makaleler ve Kitap Bölümleri}

AGOSTINI, Domenico and SHAKED, Shaul, "Two Sasanian Seals of Priests", Bulletin of the Asia Institute, New Series, vol. 27 (2013), pp. 99-105.

BRUNNER, Christopher J., "The Chronology of the Sasanian Kusansahs", Museum Notes (American Numismatic Society), vol. 19, (1974), pp. 145-164.

DERYÂYÎ, Tûrac, "Ketîbeyî Kertîr der Nekşe Receb", Nâmeye Îrân Bâstân, Sâle Evvel, Şomâreye Evvel, Behâr ve Tâbestân, 1380(hş), ss. 1-10.

DERYÂYÎ, Tûrac, "Ketibey-i Pehlevî Selûk, Dâver-i Kâbil", Ferheng, Vijeye Zaban Şenâsî, Şomâre 49-50, Behâr ve Tâbestân, 1383(hş), ss. 46-51.

FRYE, R. N. and SKJAERVO, P. O., "The Middle Persian Inscription from Meshkinshahr", Bulletin of the Asia Institute, New Series, vol. 10, Studies in Honor of Vladimir A. Livshits, 1996, pp. 53-63.

FRYE, R. N., "The Political History of Iran Under the Sasanians", The Cambridge History of Iran, vol. 3(1), (Edited by Ehsan Yarshater), 2000, pp. 116-180.

GUBAEV, A. G., S. D. Loginov and A. B. Nikitin, "Sasanian Bullae from the Excavations of Ak-Depe by the Station of Artyk", Iran, vol. 34, Publisher Taylor and Francis, 1996, pp. 55-59.

JAMES, Simon, "Stratagems, Combat, and "Chemical Warfare" in the Siege Mines of DuraEuropos", American Journal of Archaeology, v. 115, 2011, pp. 69-101.

MALEK, Hodge Mehdi and CURTIS, Vesta Sarkhosh, "History and Coinage of the Sasanian Queen Boran (AD 629-631)”, The Numismatic Chronicle (1966-), vol. 158 (1998), pp. 113-129.

MORDTMANN, Andreas D., "Zur Pehlevi-Münzkunde IV”, ZDGM, v. 33, (1879), pp. 82-142.

MORDTMANN, Andreas D., “Zur Pehlevi-Münzkunde V”, ZDGM, v. 34, (1880), pp. 1-162.

NAKSHABANDI, N. and F. RASHID, "Sassanian Dirhems in the Iraq Museum", Sumer, vol. 11/2, (1955), pp. 154-176.

SCHINDEL, Nikolaus, "Sasanian Mint Avvreviations: The Evidence of Style", The Numismatic Chronicle (1966-), v. 165, Published Royal Numismatic Society, (2005), 287-299. 
VENDÂ'Î, Mîlâd, "Behrâme Devvom der Gûyûm ve Barme Delak II, III", Sasanika Archaeology20, 2014, pp. 1-26.

YILDIRIM, Nimet, "Fars Edebiyatında Metafizik Yolculuklar", Doğu Esintileri: Iranoloji, Fars Dili ve Edebiyatı Araştırmaları Dergisi (A Journal of Iranology Studies), S. 2, Erzurum, 2014, pp. 177-212.

\section{Ansiklopedi Maddeleri}

GROPP, Gerd, "Ka'ba-ye Zardoşt", EI, vol. XV, fasc. 3, 2009, pp. 271-272.

SKJÆRVØ, Prods Oktor, "Kartir", EI, vol. XV, fasc. 6, 2011, pp. 608-628;

SKJÆRVØ, Prods Oktor, "Herzfeld and the Paikuli Inscription", EI, vol. XII, fasc. 3, 2003, pp. 298-300. 